\title{
The effect of school type on EFL teachers' burnout: The case in Turkey
}

\author{
Fatma Kimsesiz ${ }^{\text {a }}$ * \\ ${ }^{a}$ Kırşehir Ahi Evran University, School of Foreign Languages, Kirşehir, 40100, Turkey
}

\section{APA Citation:}

Kimsesiz, F. (2019). The effect of school type on EFL teachers' burnout. Journal of Language and Linguistic Studies, 15(4), 1413-1425. Submission Date:07/09/2019

Acceptance Date:11/10/2019

\begin{abstract}
Teachers are the leaders of education; their energy contributes to the learning and teaching process. In foreign language classrooms, one of the essentials of effective teaching is having highly motivated teachers. Thus, their job satisfaction and energy have a great impact on language teaching process. However, affecting teachers emotionally, physically, and psychologically, burnout may decrease the performance of the teachers and may have a negative influence on their approach towards the students or workplace during the process. The aim of this study was to examine the burnout levels of English as a Foreign Language teachers in Turkish context and to investigate any effect of school type on burnout levels when age and experience were controlled. The participants included 74 teachers of EFL teaching in public schools. The participants were asked to fill a scale, which included demographics and burnout levels on three aspects as Emotional Exhaustion, Depersonalization, and reduced Personal Accomplishment in Maslach Burnout Inventory (1981). Primarily, the findings indicated that EFL teachers commonly showed high levels of burnout. Moreover, it was revealed that as a school type, primary school had a significant effect on in three sub-dimensions of teachers' burnout levels. In consideration of the literature and findings, results are discussed and implications are provided in terms of burnout and young learners.
\end{abstract}

(C) 2019 JLLS and the Authors - Published by JLLS.

Keywords: professional burnout; EFL teachers; teaching English; school type; primary school

\section{Introduction}

Professional life is one of the most important part of our lives. The effectiveness at work is a reflection of the psychological, emotional, physical and cognitive well-being of the human being working all day and sometimes all night. The motivation and job satisfaction are strongly related factors that shape the ultimate performance expected. Thus, while the motivation and satisfaction increase the performance, negative impacts over these variables may decrease it (Gaitan, 2009).

Concerning education, teachers are considered as the prominent leaders of instruction. Along the same line, it is of utmost importance that teachers feel job satisfaction in order to build favorable results for the development of the generation. However, in the course of time, teachers, as emotional human

\footnotetext{
* Corresponding author. Tel.: +90-386-210-2114

E-mail address: fatmakimsesiz@ahievran.edu.tr
} 
beings can be affected by many factors that can bear adverse effects in terms of motivation and performance (Maslach, Jackson \& Leiter, 1996; Maslach, Shcaufeli \& Leiter, 2001).

Due to the developments in information technologies, teachers' roles have also changed forcing them to keep pace with rapid changes in education and technology. Particularly, teaching pedagogy requires the skills of using technological tools for instruction such as the ability to use computer programs, projectors, photocopying machines, interactive flat panels, tablets, and new applications compatible with them. Moreover, emotional, physical and mental exhaustion of the teachers may result in medical problems. Thus, a kind of psychological annoyance called 'burnout' may emerge due to chronic stress felt at work (Freudenberger, 1974; Maslach \& Jackson, 1981). The research in the area provides a basis for the variables to study and to predict potential reasons for the case.

\subsection{Literature review}

The concept of 'burnout' was first introduced by Freudenberger (1974) in order to provide aid and service to people in need, especially to the relating professions of human services, such as health care, social work, psychotherapy, legal services, and police work. Later, it referred to teachers who also dealt with individuals for instruction, sometimes with excessive effort and stress. Freudenberger defined the term 'burnout' as the "gradual emotional depletion, loss of motivation, and reduced commitment" (1974, p. 159). The term later became popular with the development of the Maslach Burnout Inventory in 1981 (Maslach \& Jackson, 1981) enabling initial studies of the issue commonly focusing on people who perform 'people-work' of some kind (Maslach \& Jackson, 1981, p.99).

Burnout is characterized as a "psychological syndrome of emotional exhaustion, depersonalization, and reduced personal accomplishment" (Maslach, Jackson \& Leiter, 1997, p.192). It can be encountered among individuals working with other people in some capacity. It represents an affective and physiological reaction to the chronic emotional strain of working intensively with other people. Generally speaking, professionals especially working in care giving services such as healthcare professionals, social workers and teachers can be at great risk of being exposed to burnout (Maslach, 1982).

Burnout is described by three distinct but related factors: Emotional Exhaustion, Depersonalization, and reduced Personal Accomplishment (Maslach \& Jackson, 1986). Being regarded as a key concept of the burnout syndrome due to depletion of emotional resources (Maslach et al., 1997; Shirom, 1989), emotional exhaustion is explained by Maslach (1999) as "the feelings of being emotionally overextended and emotional resources depletion, wearing out, loss of energy, and fatigue" (p. 215). This factor is believed to be caused considerably by the instability between the resources and the consumers. Among the symptoms of having emotional exhaustion are feeling tired, frustrated, restless, or nervous (Farber, 1991; Maslach \& Jackson, 1981). Teachers suffering from emotional exhaustion show that they can no longer "give of themselves to students as they once could" (Maslach, Jackson \& Leiter, 1996, p. 28).

As a second factor, depersonalization refers to developing negative attitudes and indifference to people who are in need of service. These reactions might be caused by emotional exhaustion as a defensive coping mechanism against the stress they feel at work. Teachers with depersonalization may feel indifferent displaying detached attitudes towards students as individuals when they need help (Maslach \& Jackson, 1986). Feeling cold and distant towards students, relinquishing ideals and showing cynical indifference are among the indicators of depersonalization (Maslach \& Leiter, 1997).

As a third indicator of burnout, reduced personal accomplishment refers to dissatisfaction felt by the workers. Maslach (1999) defines reduced personal accomplishment as "a decline in one's feelings of competence and successful achievement in one's work" (p. 215). An individual experiencing reduced 
personal accomplishment shows indications of reduced competence and a lack of achievement and productivity at work. They feel unable to cope with the problems (Maslach et al., 2001). As teachers feel less effective in achieving their goals, their personal accomplishment may diminish correlatively with their motivation, happiness, satisfaction and performance (Maslach \& Jackson, 1981; Maslach et al., 1996; Maslach et al., 2001). Burnout teachers may build a sense of ineffectiveness and job dissatisfaction, which in turn causes negative outcomes related with their motivation and performance at work, bringing on more physiological, mental and psychological problems. During the process, teachers may lose their energy and their sense of the value of their job.

Previous studies have shown that burnout is significantly related to particular demographic variables such as gender, age, marital status etc. (Friedman, 1991) as well as the work-related factors such as teaching experience, type of school, working hours, etc. (Friedman, 1991; Russell, Altmeier, \& Van Velzen, 1987) in terms of emotional exhaustion, depersonalization, and reduced personal accomplishment (Gold \& Grant, 1993). In another sense, Byrne (1999) claimed that some variables relating to the construct of burnout may be due to organizational and personal levels, the former referring to role conflict, work overload, decision making and social support and the latter including demographic and personal features such as locus of control and self-esteem.

According to previous related research, teachers who experience the influence of burnout exhibit a breakdown of physical health and emotional well- being (Guskey, 1988). They also show decreased willingness and callousness in the implementation of the instructional duties and avoid using innovative classroom practices. Moreover, burnout diminishes a teacher's eagerness to conduct effective implementation of the revisions to instructional and management techniques (Maslach et al., 2001). Consequently, when teachers are affected by burnout, so do the students reciprocally. On the other hand, when the needs of the students are supplied with enthusiasm, then a high level of effectiveness is much prone to be achieved. Another factor to be considered to motivate teachers on the effective implementation involves job satisfaction (Gaitan, 2009). Thus, determining the precursors of burnout is essential to cope with its adverse effects adequately. Two different techniques are suggested as struggling techniques for burnout (Hughes, 2001): The first one is direct action techniques through which teachers can manage on their own and the second one is palliative techniques which urge teachers to get counseling services in order to recover. Some of the struggling techniques are listed by Kyriacou (2001) as follows: keeping problems in perspective, avoiding confrontations, relaxing after work, discussing problems, controlling one's feelings, having a healthy home life, planning ahead and prioritizing, and recognizing one's own limitations.

Rather than burnout, engagement is applied as a term characterized by energy and motivation felt for the profession. Engagement also maintains job satisfaction and produces effective outcomes both for teacher- student interaction and for the teaching process. Bearing an optimistic approach toward the profession, engaged employees are keen on taking part in activities and organizations related with their working field (Bakker, Schaufeli, Leiter, \& Trais, 2008). Engagement can also be a good alternative in order to overcome the negative influence of burnout. It is essential to look for a way in order to struggle against the potential effects of burnout and to integrate new procedures for maintaining job satisfaction and engagement.

Considered to be one of the motivating elements of any working atmosphere, job satisfaction is generally related with meeting the needs and expectations of workers to make them feel secure and motivated during their performances. According to the findings of Küskü (2001), age, seniority, gender, academic position and salary are found to be different variables that affect the job satisfaction level of workers. 
Wong and Heng (2009) suggest that jobs should be enriched and emphasis should be placed on motivator or intrinsic areas to allow the institutions to reach towards self-actualization and satisfaction and to decrease the problems of job satisfaction and overcome the distracting elements of performance. When the motivator or intrinsic factors could be improved to provide more flexibility and more adaptability to changing conditions, and when working conditions are improved, the resulting quality of education would most certainly have to increase along with job satisfaction.

In educational contexts, burnout may appear in any phase of teaching, however within three to five years of teaching experience; teachers are most prone to experience burnout (Maslach et al., 2001). Longitudinal studies commonly concluded that burnout in educational contexts could be related to several factors such as lack of experience, poor teacher induction, absence of mentoring, and failure of the school culture. These factors can be extended to other factors such as role conflict and lack of social support from other colleagues, job withdrawal, decompensation of job performance and job dissatisfaction. Evidence from several studies reveals that burnout can mount across time rather than regressing (Maslach, 1999; Taris, LeBlanc, \& Schaufeli et al., 2005). In relation to demographic variables such as gender, age, work experience, monthly income, etc. different results have been indicated between English teachers' burnout and these variables. In a study that explored the relationship between burnout and age, gender and experience of 110 English as a Foreign Language (EFL) teachers, Uğuz (2016) found no significant relationship although teachers revealed high levels of burnout. Genç (2016) aimed to examine the relationship between burnout and learned resourcefulness. The results revealed that more than half of the teachers have moderately high level of learned resourcefulness experiencing burnout at moderate level in three aspects of Maslach Burnout Inventory. Moreover, school type was found to be significant in three burnout sub-dimensions. Hismanoğlu and Ersan (2016) investigated Turkish EFL teachers' burnout levels in relation to demographic variables using Maslach Burnout Inventory. Although the study indicated no relationship between age, gender, educational background and weekly course load, a significant relationship was found between teaching experience and institution in terms of the subscale of emotional exhaustion and reduced personal accomplishment. Moreover, a significant relationship was revealed between monthly income and living in big/small city and emotional exhaustion, and between department and administrative duty, regarding the subscale of reduced personal accomplishment. Investigating the possible causes of burnout among English teachers, their expectations for preventing teacher burnout and increasing their job satisfaction, Atmaca (2017) found out that at a low-level teaching experience was correlated with job satisfaction and burnout. Moreover, factors such as shareholders, self-efficacy, physical and social environment of the school were found to have a great role in teacher burnout. With a purpose to determine the effect of gender, marital status, subject matter, school type, educational status and seniority variables on teacher burnout, Yorulmaz and Altınkurt (2018) conducted a meta-analysis for their study on teacher burnout in Turkey. Their study concluded that gender, marital status, subject matter, and educational status had a very low effect on teacher burnout, whereas this effect was very low or low for seniority and low or medium for school type variables.

English teachers teach English as a foreign language in Turkey and new applications and reforms may bear some troubles in terms of teachers. With the reform of beginning EFL at the second grades in public schools in 2012, most of the English teachers were obliged to teach English to young learners. Although it was just a start for beginning teachers, teaching English to those little kids jumping, singing, playing and crying around was a challenge for most of the teachers who had been teaching English especially to teenagers over years and who could not have an opportunity to teach to young learners. Although the research on the reflections from teachers of young learners reveal supportive views on English classes at an early age (Gürsoy, Korkmaz \& Damar, 2013; İyitoğlu \& Alc1, 2015); some of the reflections reveal contradictions due to some factors such as crowded classrooms, time constraints, lack 
of materials such as CDs, etc. (Topkaya \& Küçük, 2010). According to Gürsoy et al., (2013), teachers may be lacking some methodological and theoretical information regarding teaching English to young learners referring to the results of their study, which revealed that although less experienced teachers prefer games and activities in teaching grammar, most experienced teachers prefer involving exercises without any contextualization. The researchers relate the findings to the fact that less experienced teachers received training on teaching English to young learners (TEYL) because of the 1997 curriculum reform. Thus, teachers without TEYL courses may be lacking of information about the recent approaches, methods, and practices in TEYL that take place especially in primary education. In their study, İyitoğlu and Alcı (2015) found out that some of the teachers were not aware of the curriculum that does not suggest notebook use and rote learning in English classes. Thus, their study suggested that teachers should be provided with information about the curriculum covering its purposes, goals and objectives in teachers' books and they need to be informed about the recent approaches and methods in TEYL.

Relevantly, current study aims to investigate the burnout levels of EFL teachers working at public schools. Hence, Maslach Burnout Inventory developed by Maslach and Jackson (1981) is used for exploring burnout levels of teachers in terms of its three different sub-dimensions -Emotional Exhaustion, Depersonalization, and reduced Personal Accomplishment. Accordingly, the study also aims to identify whether EFL teachers working at primary schools have burnout over EFL teachers working in secondary or high schools based on each of these sub-dimensions.

\subsection{Research questions}

Different from previous related research, this study specifically aimed to reveal burnout levels in different school types in Turkish context, especially for EFL teachers working in central Anatolia. Hence, the primary aim was to investigate the burnout levels of EFL teachers working at public schools and to explain whether there were any differences in EFL teachers' burnout levels according to school types. Answers for the following research questions were sought:

1. What is the level of EFL teachers' professional burnout in terms of;

a. emotional exhaustion dimension?

b. depersonalization dimension?

c. personal accomplishment dimension?

2. Is there an effect of school type on EFL teachers' burnout levels?

\section{Method}

\subsection{Participants}

74 teachers of EFL (21 males and 53 females) working in public schools in Kurşehir in an age range between 28 to $63(\mathrm{M}=36, \mathrm{SD}=6,37)$ voluntarily participated in this study. All the participants had the same first language background. $90 \%$ of the participants were graduates of ELT Department, 5\% of them were graduates of English Language and Literature Department and 5\% were graduates of other departments. Their experience in language teaching ranked between 5 to 40 years. 


\subsection{Instrument $(s)$}

In order to determine participants' burnout level in teaching EFL, Maslach Burnout Inventory (MBI) developed by Maslach and Jackson (1981) was used to identify their emotional exhaustion, depersonalization and reduced personal accomplishment level and other related factors. The survey included a form, which asked participants to reveal their demographic information about their gender, age, educational background, work experience and what kind of school they work - preschool, primary school, secondary school, or high school.

In measuring burnout, Maslach Burnout Inventory developed by Maslach and Jackson (1981) is the most commonly used scale. The Cronbach Alpha Coefficient of the questionnaire was .79. The MBI consists of 3 components of emotional exhaustion (9 items), depersonalization (5 items) and lack of personal accomplishment (8 items) totally comprising of 22 items scored on a 7-point Likert Scale ranging between 0 (never) and 6 (every day).

\subsection{Data collection procedures}

The study was carried out with EFL teachers employed at public schools affiliated to the Ministry of National Education in Kırşehir, Turkey during a week of professional education seminar to which the participants attended. For the investigation of their burnout level in teaching EFL, participants were asked to fill in the MBI. The data acquired from the questionnaires were processed in SPSS and data was analysed in accordance with the research questions.

\subsection{Data analysis}

The quantitative data collected from the participants were analysed using the Statistical Program for Social Sciences (SPSS) 21. Descriptive statistics were used to describe the research sample.

In order to identify participants' burnout level regarding the three components of emotional exhaustion, depersonalization, reduced personal accomplishment, descriptive statistics for each component in the scale were calculated. As Maslach and Jackson (1981) indicated, higher mean scores of emotional exhaustion and depersonalization correspond to higher degrees of burnout whereas lower mean scores of personal accomplishment correspond to higher burnout level. Categorization of burnout scores is given on Table 1 (Maslach \& Jackson, 1981).

Table 1. Scoring key (Maslach \& Jackson, 1981)

\begin{tabular}{cccc}
\hline $\begin{array}{c}\text { Categorization for Burnout Scores } \\
\text { on MBI-ES Categorization } \\
\text { Emotional Exhaustion }\end{array}$ & High & Moderate & Low \\
Depersonalization & 27 or over & $17-26$ & $0-16$ \\
Personal Accomplishment & 13 or over & $7-12$ & $0-6$ \\
\hline
\end{tabular}

For the description of the relationship between the burnout level of participants and their demographic information related with age, experience year, and the school where they work; Descriptive Statistics and One-Way ANCOVA analysis were applied. The three subscales - emotional exhaustion, depersonalization, reduced personal accomplishment, - of teacher burnout were labelled as the 
dependent variables and demographic information of the participants were labelled as independent variables.

\section{Results}

\subsection{Burnout Levels of EFL Teachers: A General Overview}

The first research question attempted to identify burnout level of teachers in terms of emotional exhaustion, depersonalization, and reduced personal accomplishment. Table 2 shows the frequency and percentages of professional burnout subscales of the participants revealed by MBI.

Table 2. Frequency and percentages of professional burnout subscales

\begin{tabular}{|c|c|c|c|c|c|c|}
\hline \multirow[t]{3}{*}{ Item } & \multicolumn{6}{|c|}{ Level } \\
\hline & \multicolumn{2}{|c|}{ Low } & \multicolumn{2}{|c|}{ Moderate } & \multicolumn{2}{|c|}{ High } \\
\hline & $\mathbf{F}$ & $\%$ & $\mathbf{F}$ & $\%$ & $\mathbf{f}$ & $\%$ \\
\hline $\begin{array}{l}\text { Emotional } \\
\text { Exhaustion }\end{array}$ & 20 & 22.7 & 49 & 55.7 & 19 & 21.6 \\
\hline Depersonalization & 2 & 2.3 & 42 & 47.7 & 44 & 50.0 \\
\hline $\begin{array}{c}\text { Personal } \\
\text { Accomplishment }\end{array}$ & 3 & 3.4 & 27 & 30.7 & 58 & 65.9 \\
\hline
\end{tabular}

According to Table 2, 22.7\% of the participants have low levels of emotional exhaustion whereas $21.6 \%$ of them have high levels of emotional exhaustion. Regarding their burnout level of depersonalization, $2.3 \%$ of EFL teachers have low levels of depersonalization while half of them (50\%) have high levels of depersonalization. In addition, it is found out that $3.4 \%$ of EFL teachers have low levels of personal accomplishment whereas more than half of them $(65.9 \%)$ have high levels of lack of personal accomplishment. Table 3 shows the mean value and standard deviation of the variables.

Table 3. Descriptive statistics of the variables

\begin{tabular}{cccc}
\hline Variable & Number of Respondents & Mean & SD \\
Total Burnout Level & 88 & 2.85 & .601 \\
Emotional Exhaustion & 88 & 2.36 & .775 \\
Depersonalization & 88 & 2.60 & .736 \\
Reduced Personal & 88 & 3.56 & .744 \\
Accomplishment & & & \\
\hline
\end{tabular}

As displayed in Table 3, the mean value of professional burnout variable was around $2.85(\mathrm{SD}=.601)$, and the greatest mean value among its dimensions was measured as $3.56(\mathrm{SD}=.736)$ for reduced personal accomplishment and the lowest value was counted with $2.36(\mathrm{SD}=.775)$ for emotional exhaustion.

\subsection{The Effect of School Types on Burnout Levels}

Second research question aimed to investigate whether there were any differences in EFL teachers' burnout levels according to the school type they work when age and experience were controlled. For this aim, a one-way ANCOVA was adopted with school type as the factor, burnout level as the dependent variable and academic experience and age as covariates. Mean values for each school type were as follows: 
Table 4. Mean burnout levels for school types

\begin{tabular}{ccccc}
\hline School Type & Mean & Std. Error & \multicolumn{2}{c}{$95 \%$ Confidence Interval } \\
& & & Lower Bound & Upper Bound \\
Primary School & $69.163^{\mathrm{a}}$ & 3.274 & 62.632 & 75.693 \\
Secondary School & $57.732^{\mathrm{a}}$ & 2.307 & 53.130 & 62.334 \\
High School & $57.326^{\mathrm{a}}$ & 2.370 & 52.598 & 62.054
\end{tabular}

a. Mean values were adjusted in accordance with covariates

Table 4 showed that teachers in primary school have highest burnout levels $(\mathrm{M}=69.16 ; \mathrm{SE}=3.27)$ which was then followed by secondary schools $(\mathrm{M}=57.73 ; \mathrm{SE}=2.30)$. The least burnout level was found in high school context $(\mathrm{M}=57.32 ; \mathrm{SE}=2.37)$. These differences revealed statistically significant results even when age and academic experience were controlled $\mathrm{F}(2.69)=5.075, \mathrm{p}=.009)$. For pairwise comparisons, primary school burnout levels were higher than both secondary school $(\mathrm{p}<.05)$ and high school $(\mathrm{p}<.05)$. No significant difference was found between high school and secondary school.

After finding out significance between school type and burnout, significance of each burnout components was analysed. A one-way ANCOVA was adopted with school type as the factor, total emotional exhaustion level as the dependent variable and academic experience and age as covariates in order to investigate any effect of school type on EFL teachers' emotional exhaustion burnout levels. Mean values for each public school type were as revealed in Table 5.

Table 5. Mean burnout levels regarding emotional exhaustion for school types

\begin{tabular}{ccccc}
\hline School Type & Mean & Std. Error & & $95 \%$ Confidence Interval \\
& & & Lower Bound & Upper Bound \\
Primary School & $23.325^{\mathrm{a}}$ & 1.577 & 20.178 & 26.472 \\
Secondary & $19.523^{\mathrm{a}}$ & 1.112 & 17.306 & 21.741 \\
School & & & & 20.103 \\
& $17.825^{\mathrm{a}}$ & 1.142 & 15.547 &
\end{tabular}

a. Covariates appearing in the model are evaluated at the following values: age $=36.4459$, work place experience $=13.3108$.

As revealed in table 5, teachers in primary school have highest burnout levels ( $\mathrm{M}=23.32 ; \mathrm{SE}=1.57)$. It was followed by secondary school context $(\mathrm{M}=19.52 ; \mathrm{SE}=1.12)$ and then in high school context with the least burnout level $(\mathrm{M}=17.82 ; \mathrm{SE}=1.14)$. Even when age and academic experience were controlled; these differences were found to have been statistically significant $F(2.69)=3.852 \mathrm{p}=.026$. For pairwise comparison, primary school burnout levels in emotional exhaustion were higher than both secondary school ( $\mathrm{p}=.149)$ and high school ( $\mathrm{p}=.023)$. No significant difference was found between high school and secondary school.

As to the effect of school type on EFL teachers' burnout levels in depersonalization, a one-way ANCOVA was also adopted with school type as the factor, total value of depersonalization as the dependent variable and academic experience and age as covariates. Mean values for each public school type were as follows: 
Table 6. Mean burnout levels regarding depersonalization for school types

\begin{tabular}{ccccc}
\hline School Type & Mean & Std. Error & & $95 \%$ Confidence Interval \\
& & & Lower Bound & Upper Bound \\
Primary School & $13.993^{\mathrm{a}}$ & .964 & 12.069 & 15.917 \\
Secondary & $12.307^{\mathrm{a}}$ & .680 & 10.951 & 13.663 \\
$\quad$ School & & & & 13.389 \\
High School & $11.996^{\mathrm{a}}$ & .698 & 10.603 & \\
\hline
\end{tabular}

a. Covariates appearing in the model are evaluated at the following values: age $=36.4459$, work place experience $=13.3108$.

As displayed in Table 6 teachers in primary school have highest burnout levels in depersonalization $(\mathrm{M}=13.99 ; \mathrm{SE}=.964)$ which was then followed by secondary school $(\mathrm{M}=12.30 ; \mathrm{SE}=.680)$. The least burnout level was found in high schools $(\mathrm{M}=11.99 ; \mathrm{SE}=.698)$. No significant difference was found when both age and academic experience were controlled; F (2.69) $=1.483 \mathrm{p}=.234$. For pairwise comparison, primary school burnout levels in depersonalization were higher than both secondary school $(\mathrm{p}=.456)$ and high school $(\mathrm{p}=.319)$. There was no significant difference between high school and secondary school.

Finally, with respects to the effect of school type on EFL teachers' reduced personal accomplishment level, a one-way ANCOVA was adopted with school type as the factor, burnout level in personal accomplishment as the dependent variable and academic experience and age as covariates. Mean values for each public school type were as follows:

Table 7. Mean burnout levels regarding reduced personal accomplishment for school types

\begin{tabular}{ccccc}
\hline School Type & Mean & Std. Error & 95\% Confidence Interval \\
& & & Lower Bound & Upper Bound \\
Primary School & $30.128^{\mathrm{a}}$ & 1.639 & 26.859 & 33.398 \\
Secondary & $27.489^{\mathrm{a}}$ & 1.155 & 25.186 & 29.793 \\
School & & & 24.684 \\
High School & $27.051^{\mathrm{a}}$ & 1.186 & 29.417 \\
\hline \multicolumn{4}{c}{ a. Covariates appearing in the model are evaluated at the following values: age $=36.4459$, work place } \\
\multicolumn{4}{c}{ experience $=13.3108}$.
\end{tabular}

Table 7 displays that teachers in primary school have highest burnout levels ( $\mathrm{M}=30.12 ; \mathrm{SE}=1.63)$, then secondary school context $(\mathrm{M}=27.48 ; \mathrm{SE}=1.15)$ and then high schools $(\mathrm{M}=27.051 ; \mathrm{SE}=1.18)$ with the least burnout level. These differences were not found to have been statistically significant even when age and academic experience was controlled $(\mathrm{F}(2.69)=1.234 \mathrm{p}=.297)$. For pairwise comparison, primary school burnout levels in emotional exhaustion were higher than both secondary school $(\mathrm{p}=.559)$ and high school $(\mathrm{p}=.427)$. No significant difference was found between high school and secondary school.

\section{Discussion}

This study firstly attempted to identify the burnout levels of EFL teachers concerning their emotional exhaustion, depersonalization, and reduced personal accomplishment. The findings revealed that one fourth of the participants (21.6\%) revealed high levels of emotional exhaustion, exactly half of the participants (50\%) reported to have high levels of depersonalization, and more than half of the participants (65.9\%) reported to have high levels of lack of personal accomplishment. As claimed by 
the research in the area (Maslach \& Jackson, 1981; Farber, 1991; Genç, 2016; Uğuz, 2016), teachers may have high levels of burnout in flux. Accounting for the previous studies, it was noted that those teachers with emotional exhaustion feel less effective in achieving their goals (Maslach \& Jackson, 1981), feel tired and frustrated as well as restless and nervous (Farber, 1991). Teachers with depersonalization reveal that they feel cold and distant towards students and behave cynically (Maslach $\&$ Leiter, 1997).

Moreover, it is claimed that teachers may increase depersonalization as a defensive mechanism towards emotional exhaustion (Maslach \& Jackson, 1986). Additionally, teachers who experience reduced personal accomplishment may show lack of achievement and productivity at work that causes decrease in their motivation, happiness, satisfaction and performance (Maslach \& Jackson, 1981; Maslach et al., 1996; Maslach et al., 2001). Regarding these indications, it is possible to state that high levels of emotional burnout may cause feeling emotionally drained which also stimulates depersonalization and finally reduced personal accomplishment with a negative impact on the relationship between the teacher and the students (Gaitan, 2009). It may be substantially hard for a burnout teacher who feels tired, frustrated, nervous, and cynical; besides lack of motivation, happiness, and job satisfaction to achieve his/her professional goals and to maintain an effective and healthier environment for education.

Within this context, it can be a preferable idea to increase job satisfaction among teachers from the very beginning of their academic and professional life (Küskü, 2001; Wong \& Heng, 2009). As explained in the literature part, engagement particularly in activities and organizations can be a favourable alternative to cope with the influence of burnout (Bakker et al., 2008). Kyriacou (2001) also listed some struggling techniques such as keeping problems in perspective, avoiding confrontations, relaxing after work, discussing problems, controlling one's feelings, having a healthy home life, planning ahead and prioritizing, and recognizing one's own limitations. Including but not limited to these suggestions, burnout can be a matter of interest both with precursor and with coping techniques.

As previously explained, some demographic variables such as age, gender, experience year, etc. were supposed to exert an influence on burnout. Although some of the studies found a connection between demographic variables on burnout, (Russell et al., 1987; Friedman, 1991; Gold \& Grant, 1993; Gaitan, 2009); some could not (Kurtoğlu, 2001; Uğuz, 2016,).

Alternatively, this study aimed to identify whether there were differences in EFL teachers' burnout levels according to the school type they work. As revealed by the results, there is a significant effect of primary school rather than secondary school and high school as school type on EFL teachers' burnout. As previously mentioned, with a reform of starting age for learning English by the Ministry of Education in Turkey, most of the English teachers were obliged to teach English to young learners. Although some of the teachers voluntarily undertook the responsibility and felt in favour of starting EFL at an early age (Gürsoy et al., 2013; İyitoğlu \& Alc1, 2015), some of the teachers reflected that the process was problematic due to some implementation deficiencies (Topkaya \& Küçük, 2010). These contradictions may result from the fact that most of the experienced teachers could not have TEYL courses that began after 1997 reform. Regarding the issue, it can be beneficial to introduce TEYL methodology, techniques and principles to teachers working in primary schools. Moreover, intern programmes for ELT department students may include primary schools among their contracted institutions that will enable undergraduate students to meet the environment of teaching English to young learners in case they work at a primary school hereafter. 


\section{Conclusions}

The study aimed to investigate the burnout levels of EFL teachers who participated in the study in terms of three dimensions of MBI- emotional exhaustion, depersonalization and reduced personal accomplishment. In the light of the findings, the teachers who participated in the study commonly showed high levels of burnout. In order to have a favourable, effective, successful education environment both for teachers and for students, resolving the thread of burnout can be plausible. As previously mentioned, following a path through struggling techniques can be a feasible way to construct a profitable outcome.

Regarding the second research question which investigated if there were any differences in EFL teachers' burnout levels according to the school type they work, it was discovered that primary school as a school type had a significant effect on burnout. It can result from the fact that, through a reform in Education in 2012 about starting age to learning English, some teachers who had little or no experience had to work in primary schools with young learners. Thus, the process can sound challenging especially for teachers who could not have TEYL courses during their undergraduate programme. Thus, organising seminars about TEYL methodology for teachers working in primary schools and involving primary schools for internship programmes can produce effective results in order to decrease teacher burnout in primary schools and to increase engagement and job satisfaction likewise.

\section{Acknowledgements}

I would like to thank to Asst. Prof. Emrah DOLGUNSÖZ at Bayburt University who inspired me to study on burnout of EFL teachers and provided valuable insights in each step of this study.

\section{References}

Atmaca, Ç. (2017). A burning issue among English teachers: Reflections of in-service teachers on job satisfaction and burnout. ELT Research Journal, 6(1), 89-115.

Bakker, A. B., Schaufeli, W. B., Leiter, M. P., \& Taris, T. W. (2008). Work engagement: An emerging concept in occupational health. Work \& Stress: An International Journal of Work, Health \& Organisations, 22(3), 187-200.

Byrne, B. (1999). The nomological network of teacher burnout: a literature review and empirically validated model. In R. Vandenberghe and A.M. Huberman (Eds.), Understanding and preventing teacher burnout: A sourcebook of international research and practice (pp.15-37). Cambridge, UK: Cambridge University Press.

Farber, B. A. (1991). Crisis in education: Stress and burnout in the American teacher. San Francisco: Jossey-Bass.

Freudenberger, H. J. (1974). Staff burnout. Journal of Social Issues, 30(1), 159-165.

Friedman, I. A. (1991). High- and low-burnout schools: School culture aspects of teacher burnout. The Journal of Educational Research, 84(6), 325-333.

Gaitan, P. (2009). Teacher Burnout Factors as Predictors of Adherence to Behavioral Intervention. (Unpublished doctoral dissertation). University of Minnesota. 
Genç, G. (2016). Learned resourcefulness and burnout levels of English teachers. International Journal of Psychology and Educational Studies, 3(1), 1-13.

Gold, Y. \& Grant, R.A. (1993). Teachers managing stress and preventing burnout: The professional health solution. London: Falmer.

Gürsoy, E., Korkmaz, S. Ç., \& Damar, A. E. (2013). Foreign language teaching within 4+ 4+ 4 education system in Turkey: Language teachers' voice. Eurasian Journal of Educational Research, 53, 59-74.

Guskey, T. R. (1988). Teacher efficacy, self-concept, and attitudes toward the implementation of instructional innovation. Teaching and teacher education, 4(1), 63-69.

Hismanoglu, M., \& Ersan, Y. (2016). Investigating Turkish EFL teachers' burnout levels in relation to demographic variables. Journal of Educational \& Instructional Studies in the World, 6(4).

Hughes, R. E. (2001). Deciding to leave but staying: teacher burnout, precursors and turnover. The International Journal of Human Resource Management, 12(2), 288-298.

İyitoğlu, O., \& Alc1, B. (2015). A qualitative research on 2nd grade teachers' opinions about 2nd grade English language teaching curriculum. İlkögretim Online, 14(2).

Kurtoğlu, Ü. (2001). An evaluation of ELT teachers' vocational burnout according to some variables (Unpublished master's thesis). Kafkas University, Kars, Turkey.

Küskü, F. (2001). Dimensions of employee satisfaction: A state university example. METU Studies in Development, 2 (3/4), 399-430.

Kyriacou, C. (2001). Teacher stress: directions for future research. Educational Review, 53(1), 27-35.

Maslach, C. (1982). Burnout: The cost of caring. New York: Prentice-Hall.

Maslach, C. (1999). Progress in understanding teacher burnout. In R. Vandenberghe and A.M. Huberman (Eds.), Understanding and preventing teacher burnout: A sourcebook of international research and practice. (pp. 211-222). Cambridge, UK: Cambridge University Press.

Maslach, C., \& Jackson, S. E. (1981). The measurement of experienced burnout. Journal of Occupational Behavior, 2, 99-113.

Maslach, C., \& Jackson, S.E. (1986). MBI: Maslach Burnout Inventory, Manuel Research Edition. Palo Alto, CA: Consulting Psychologists Press.

Maslach, C., Jackson, S.E., \& Leiter, M.P. (1996). MBI: The Maslach Burnout Inventory: Manual, Consulting Psychologists Press, Palo Alto, CA, 4-20.

Maslach, C., Jackson, S. E., Leiter, M. P. (1997). Maslach Burnout Inventory: 3rd edition. In Zalaquett, C. P., Wood, R. J. (Eds), Evaluating stress: A book of resources (pp. 191-218). Lanham, MD: Scarecrow Press Inc.

Maslach, C., \& Leiter, M.P. (1997). The truth about burnout: how organizations cause personal stress and what to do about it. San Francisco: Jossey Bass.

Maslach, C., Schaufeli, W. B., \& Leiter, M. P. (2001). Job burnout. Annual Review Psychology, 52, 397-422.

Russell, D. W. E., Altmaier, D., \& Van, V. (1987). "Job-related stress, social support, and burnout among classroom teachers". Journal of Applied Psychology, 72(2), 269-274. 
Shirom, A. (1989). Burnout in work organizations. In C. L. Cooper \& I. Robertson (Eds.) International Review of Industrial and Organizational Psychology, (pp.26-48). N.Y: Wiley.

Taris, T. W., Le Blanc, P. M., Schaufeli, W. B. \& Schreurs, P. J. G. (2005). Are there causal relationships between the dimensions of the Maslach Burnout Inventory? A review and two longitudinal tests. Work \& Stress, 19, 238-255.

Topkaya, E. Z., \& Küçük, Ö. (2010). An evaluation of 4th and 5th grade English language teaching program. İlköğretim Online, 9(1), 52-65.

Uğuz, S. (2016). A study on the professional burnout of EFL teachers at vocational and technical Anatolian high schools in Adana (Unpublished Master's Thesis). Çukurova University, Adana, Turkey.

Wong, E., \& Heng, T.N. (2009). Case study of factors influencing jobs satisfaction in two Malaysian Universities. International Business Research, 2(2), 86-98.

Yorulmaz, Y. İ., \& Altınkurt, Y. (2018). The examination of teacher burnout in Turkey: A metaanalysis. Turkish Journal of Education, 7(1), 34-54.

\section{Okul türünün İngilizce öğretmenlerinin tükenmişlik seviyelerine etkisi: Türkiye örneği}

\section{$\ddot{O} \mathbf{z}$}

Öğretmenler eğitimde liderdir. Onların enerjileri öğrenme ve öğretme sürecine katkı sağlar. Yabancı dil derslerinde etkili öğretimin esaslarından biri yüksek motivasyonlu öğretmenlere sahip olmaktır. Bu yüzden, onların mesleki doyumluluğu ve enerjisi dil öğrenme sürecinde büyük bir etkiye sahiptir. Bununla birlikte, ögretmenleri duygusal, fiziksel ve psikolojik olarak etkileyen tükenmişlik, öğretmenlerin performansını düşürebilir ve süreç boyunca öğrencilere veya çalışma alanına karşı yaklaşımlarında olumsuz etki yaratabilir. Bu çalışmanın amacı yabancı dil olarak İngilizce öğretmenlerinin tükenmişlik seviyelerini incelemek ve yaş ve tecrübe kontrolünde okul türünün tükenmişlik seviyesine etkisini araştırmaktır. Katılımcılar devlet okullarında görev yapmakta olan 74 İngilizce öğretmeninden oluşmaktadır. Katılımcılardan kendileri hakkında demografik bilgilerin ve Maslach Tükenmişlik Ölçeğinde (1981) yer alan Duygusal Tükenmişlik, Benlik Kaybı ve Kişisel Başarı Yetersizliği gibi üç aşamada tükenmişlik seviyelerinin bulunduğu bir ölçeği tamamlamaları istenmiştir. İlk olarak, bulgular genel olarak İngilizce öğretmenlerinin yüksek tükenmişlik seviyesine sahip olduğunu göstermiştir. Ayrıca, bir okul türü olarak ilkokulun öğretmenlerin tükenmişlik seviyelerinin üç alt boyutuna önemli bir etkisinin olduğu saptanmıştır. Literatür ve bulgular göz önünde bulundurularak sonuçlar tartışılmış ve çıkarımlarda bulunulmuştur.

Anahtar sözcükler: mesleki tükenmişlik; İngilizce öğretmenleri; İngilizce öğretimi; okul türü; ilkokul

\section{AUTHOR BIODATA}

Dr. Fatma Kimsesiz got her Master of Arts degree from the English Language Teaching Department, Atatürk University and completed his doctoral studies at the English Language Teaching Department, Atatürk University. She currently works as an Assistant Professor in the Department of Translation and Interpreting, School of Foreign Languages, Kırşehir Ahi Evran University. 